\title{
A Model of Communication to Empower Fisherman Community in Bengkalis Regency
}

\author{
${ }^{1}$ YASIR, ${ }^{2}$ NURJANAH, ${ }^{3} \mathrm{CHELSY} \mathrm{YESICHA}$ \\ 1,2,3 Department of Communication Science of Social and Political Science Faculty (FISIP) of \\ Universitas Riau, JI. HR Soebrantas KM 12,5 Pekanbaru 28293 \\ email: ${ }^{1}$ yasir.jufri@unri.ac.id; ${ }^{2}$ janah_kom@yahoo.com; ${ }^{3}$ chelsy.yesicha@lecturer.unri.ac.id
}

\begin{abstract}
Fishermen are generally still poor and use traditional way. The aims of this research are to understand the empowerment of communication pattern, to explain the media used, and to describe the model of government communication in empowering fishermen in Bengkalis. This research uses qualitative method. The research result shows that the patterns of communication are done through mentoring and counseling, socializing and establishing vocational schools of fishery, providing tools and capital facilities, building fishing villages, and developing villages' tourism. The media used are website and released in the print media, billboards and banners, calendars and posters, and films. The model of communication in empowering fishermen relies on Marine and Fisheries Departments, especially Field Officers (PPL), and by coordinating with other departments such as academician, police, universities and society.
\end{abstract}

Keywords: communication, empowerment, media, counseling, fishermen.

\section{Introduction}

The management of fishery and coastal resources becomes one of the important agendas in the current national development policy. The attention of the Ministry of Fisheries and Marine Affairs (KKP) of the Republic of Indonesia towards maritime/ marine development is still does not improve the life quality of coastal communities, especially fishermen. The low standard of coastal communities' living and limited access to get assets and financial sources is a major problem for fishermen. In this case, Amanah (2010: 1) reveals that coastal communities have a distinctive life, face directly a harsh ecosystem and sources of life that depend on coastal and marine resources. Coastal communities, especially traditional fishermen, are still entangled by poverty and backwardness problems. Amanah (2010: 17) also explained that the condition of coastal communities and fishermen has not been free from the problems encountered including limited access to capital resources and the weakness of communication role in bridging the gap that occurred.
It is not yet related to marine ecological issues and socio-economic vulnerability or conflicts to coastal communities. One of the fundamental problems in the development and improvement of the quality of fishermen's life is the lack of government effort in empowerment and communication. The government ways to communicate do not improve the fishermen community's welfare yet. The process of participative communication, dialogical, and motivational actually becomes very important to improve the fishermen community's welfare.

The government does not optimally motivate the fishermen which cause them living a life far from prosperity. Bengkalis district as one of the districts in Indonesia is a region of fishermen. In this district, most of the people living in the coastal areas are still using traditional way in fishing. Fishermen are generally using longline fishing gear, gill nets, seine trawl, "langgai" and ponds. The fish they catch are only for the daily use and is simply sold to the local people or is made into salted fish.

Nurjanah (2015: 129) reveals the

Received: January 04, 2017, Revision: July 25, 2017, Accepted: December 14, 2017

Print ISSN: 0215-8175; Online ISSN: 2303-2499. DOI: http://dx.doi.org/10.29313/mimbar.v33i2.2135.228-237

Accredited B based on the decree No.040/P/2014, valid on February, 18, 2014 until February, 18, 2019. Indexed by DOAJ, Sinta, IPI 
traditional fishermen's competition with large capitalized fishermen using bottom gill net is a great threat to the traditional fishermen, especially in Bantan District. The bottom gillnet threatens the survival of the families and the viability of aquatic resources since nearly $100 \%$ of these traditional fishermen rely on their traditional way to catch the fish.

The further impacts are increasingly difficult to capture, resulting in increased inequalities, declining incomes, and poverty, as well as lack of prosperity among traditional fishing communities. The scarcity of fishery resources, especially the types of fish with high economic value, prospective markets, and fishing gear used are factors considered as sources of conflict occurred between and among the fishermen. The intensity of conflict is determined by the degree of difference of fishing technology used by the fishermen, the limited territorial distribution of species, and the number of fishermen who fight over it.

The government has a strategic role to transform and empower this community, as well as the efforts and cooperation of other non-governmental institutions such as nongovernmental organizations (NGOs), private sector through corporate social responsibility (CSR) programs, universities, and community in general. However, what often happens is the suspicion or distrust of traditional fishermen against the government because of repeated attitudes from the Department of Fisheries and officials who did not at their side in handling the cases occurred. For example, the conflict between the traditional fishermen and the large capital fishermen who use the bottom gillnets.

In addition, the lack of sustainable communication through mentoring, counseling, coaching, or other efforts from the national government, provincial, and district levels in empowering the community has not yet changed the level of fishermen's welfare. Likewise, NGOs, universities or other institutions which give less concern and show no active interest in the efforts to transform the coastal environment or fishermen communities into a better condition.

In this case, Widjajanti (2016: 2486) describes the strategy and model of building the structure of fishing village in Sukolilo beach area of Surabaya to improve the fishermen's family welfare. Widjajati reveals that the management and structuring of coastal areas or resources can improve the economic level of community and local government. With appropriate spatial strategies and models, the fisherman community can improve the quality of their life and environment. But what is interesting in this research is that the economic potential of high fishermen society is not followed by facilities and supporting infrastructure. In other words, the government should evaluate policies and programs to further improve the quality of fishermen through better infrastructure and facilities development.

Sartika (2011: 111) also revealed that the government policy had not improved the welfare of fishermen in Pangandaran District. One of the fishermen empowerment policies offered is the government intervention in fisheries business, both traditional and clusterbased industries. Similarly, Govindaraju and Mabel (2010: 128), conducted research in villages which already equipped with a village knowledge center (VKG) developed by a local agency in serving the community related to e-governance, e-agriculture, e-educatio n, e-health, and other facilities for free. This research reveals the role of this body through technological adoption in empowering communities of fishermen in this village.

The purpose of this study is to explore or understand the communication process in empowering fishermen community of Bengkalis Regency, Riau Province. Apart from the existing problems, there are three purposes of this study. Firstly, to understand the forms of communication in empowering fishermen community conducted by the government. Secondly, to find out the media used by the government in improving the fishermen's welfare in Bengkalis Regency. Thirdly, to understand the model of communication in empowering fishermen in Bengkalis Regency.

\section{Research methods}

In this research, the researchers use a qualitative research method with explorative research type. This research seeks to collect, compile, and interpret the existing data, and analyze the object under study by referring to the research procedures with mainly collecting qualitative data using interpretation. Then, the researchers present data in the form of statements or sentences systematically to explain the substance of the problem in order to obtain a clear picture of the communication model of fishermen community empowerment in Bengkalis Regency, Riau Province.

The subjects of this research are 
some government apparatuses in Fisheries and Maritime Department of Bengkalis Regency, some members of fishermen community groups in Bengkalis Regency, and field assistance officers (PPL). The informant as a subject was chosen purposively according to the data requirement of this research. The object of this research is the communication model of fishermen community empowerment in Bengkalis Regency. The Data collection techniques used are interviews, direct observation, and documentation. Data were analyzed with interactive data analysis components as developed by Miles and Huberman. To get the data trustworthiness, it is necessary to take inspection techniques according to the existing conditions. Implementation of inspection techniques based on a number of certain criteria, among others, is the degree of credibility (Moleong, 2010: 173). The techniques to check the level of credibility of this study are by performing perseverance observations, triangulation, and peer checking through discussion.

\section{Empowerment and Participatory Communication}

Communication and society are two complementary sides (Hamijoyo, 2005: 4). Social dynamics that take place in a society will affect the behavior of communication played by every individual in the community. Similarly, the communication process will affect and reflect the lifestyle of a society since communication is never occurs in the vacuum social-cultural space. Communication between humans always takes place in a value-packed atmosphere, such as tradition, customs, culture, ideological religion, and political orientation.

Widjajanti (2016) reveals that the empowerment of the community is to have the power, strength, or ability to identify potentials and problems, and to be able to determine their own alternative solutions (in Zulfera et al. 2014: 149-158). To enable people to have their own problem-solving skills is by giving them a form of communication which provide a free conditions to talk freely and express themselves openly according to the value they have. Therefore, unidirectional communication model or a linear model is certainly not appropriate in the context of communication empowerment. Appropriate approach or model of communication is the one that allows the exchange of information between the components in the communication process with many dimensions. Therefore, the approach used in this study is a participatory communication model. This model assumes that humans are not passive communicants, but the result of their social environment (Sulistyowati, et al., 2005: 87).

The essence of this empowerment communication model is the communication process which makes it possible for and reckons the emergence of new ideas at the time communication is in progress. The main concept of this participatory communication is centered on society. Thus, this model shows interactive situations among the parties communicate. This model underlies the emergence of the Appropriate Communication for Development of Communication (ACDC) program or called "The Right Communication for Community Development". This program uses a method of learning which is essentially means "to help people help themselves". Communicators do not impose a message to the communicant through any media. Instead, they would invite and facilitate the communicant to be able to: (1) identify their own problems; (2) analyze the problem, its meaning, and what to do; (3) take action to solve the problem.

Nugroho, et al. (2016: 254) explains that community empowerment is one of the keys success in running a development of a region. The empowerment program is carried out with models, shapes and different strategies. The suitable model of empowerment is always categorized by participatory communication. This kind of communication is the most effective and valuable when applied to groups within the community. In groups, each person is given an opportunity to learn in adults' way, rather than simply transferring knowledge without digging it first. This concept of participatory communication is an approach that sees the initiative of the people as the main development resource and views their material and spiritual welfare as the goal to be achieved through the development process. Thus, development is not only measured by the economic growth, but should also be measured by answers to the question of what happens to poverty, unemployment, and inequality.

\section{Forms of Communication in Empow- ering Fishermen in Bengkalis}

Bengkalis Regency is one of regencies in Riau Province, Indonesia. Its territory includes the eastern part of the Sumatra and 
some small islands, with an area of $7,793.93$ $\mathrm{km}^{2}$. Bengkalis Regency is largely a coastal area with a length of 722 kilometers of beach and has 16 large and small islands. The area consists of many villages whose inhabitants rely on marine resources for living. In addition to having extensive marine waters, Bengkalis district is also flowed by many rivers and has a number of lakes. It is very suitable and potential for the development of fishery cultivation, both freshwater fish, brackish and sea. Bengkalis district government through the Office of Marine and Fisheries has divided the two zones of sector development, especially for fishery cultivation. For the cultivation of freshwater fishery, the focus is on District of Bukit Batu, Mandau, Pinggir, and Siak Kecil. While cultivation of brackish water and sea water put in Bantan, Bengkalis, Rupat, and Northern Rupat District.

To improve the welfare of fishermen Bengkalis Regency, the government has many forms of communication to empower them. The main strategy of communication to empower the fishermen is based on the Development Planning Meeting (Musrembang). There are five shapes of communication to empower the fishermen community. First, communication that uses mentoring and counseling. Communications of empowerment conducted by Bengkalis government through the Office of Marine and Fisheries (DKP) rely heavily on field assistance officers (PPL). Some programs such as the Joint Business Group (KUB) development activities and development activities of the Processing and Marketing Group (POKLAHSAR) are located directly under the Marine and Fisheries Service. The role of the PPL is to provide assistance as an extension of the government, even the spearhead of the program and the main form of communication that plays an important role to provide understanding to the fishing communities.

The function of field facilitators (PPL) is to transform a society into a better direction in accordance with existing innovations. The officers are placed directly in the office of every districts, so that they are more likely to plunge into the fishing community, interact and communicate directly than employees in the office who only serve as technical implementers for administration. Some of the tasks of PPL according to the Decree of the Head of the Office of Marine and Fisheries are to conduct inventory and identify the data of the joint business group (KUB); to help facilitate the making of fisherman membership card (KTAN; to provide assistance, counseling and guidance of administrative and financial management of KUB; to facilitate easy access to business capital, production facilities, technology and markets; to solve fishermen problems; and monitors, evaluates, and reports the results of the implementation of mentoring activities to relevant budget users (KPA) and SKPD according to technical guidelines.

In addition to the assistance, the form of communication deliver by the government of Bengkalis Regency is to conduct various extension activities, which involves various universities such as University of Riau and other universities from Java. The form of communication activities through the counseling as explained by the marine and fishery agencies is aimed to increase awareness and welfare of the community, especially in improving their skills in cultivating or processing the results of the arrest. Community and fishermen groups are given training in fishing and fish processing. In this case, the Head of Coastal and Small Islands said:

"The fishermen have been traditionally processing the fish catch into fish crackers, Abon (fish floss), and also the seaweed, but it is not yet widespread. Some of them have already been made; we just help to increase the hygienic and packaging of the products. They are also given counseling by the expert, academician from universities of Java, and also speaker from local staff. The products' packaging could be in forms of fish crackers, pilus (snack), sweets seaweed, and also salted fish"(interview, September 5, 2016).

Fishing communities are already have their own knowledge in processing their catch. However, many of them still traditionally do the cultivating according to the old experience that is usually done in generations, so that it is lack of quality and not packaged properly because they do not get proper knowledge. In addition, the main constraints associated with marketing are the limited and less welcome market. The development of technology has already advanced, but people cannot utilize the media optimally to increase and promote their products.

Related to this, the government uses relevant agencies to empower and develop the processing and marketing groups through field assistants' officers (PPL) which is different from before. Some of their duties are to identify, to facilitate business permits, 
to provide assistance or counseling, to assist in accessing business capital, to help a report, to record market price lists and fish suppliers, and to monitor or evaluate. The existence of field assistants is to optimize the government programs. The existence of PPLs is placed in centers of empowerment programs or government activities. Some of the focus points of government attention are those who have easy fishing bases to be fostered through groups of fishermen. Some places are built in Bengkalis district, precisely at the village of Meskom; and District Bantan located in the village of Pambang Pesisir.

Second, communication through socialization and establishment of vocational schools for fisheries. The government through DKP conducts some socialization related to existing programs, such as social assistance for the fishermen. This socialization activity aims to improve the fishermen understanding as beneficiaries. This socialization also aims to provide an understanding of the flow of processes of planning, implementation, and the accountability. The socialization activities are conducted in order to avoid trouble in the future. The target of socialization is fishermen group and fishery processing group.

The forms of socialization are mostly done through annual events such as festivals, competitions, and others. Indeed some socialization is less effective since it is often ceremonial and uncertainty. This is just an appeal through official speech, billboards, calendar, and other media. Nevertheless, communication channels to empower communities must vary, in the media and communication activities.

Fishermen empowerment program is supported in long-term by building a special vocational school of fisheries. This school is a collaboration and cooperation among related agencies. The existence of this school is expected to change the traditional perspective of society. Unfortunately, however, the location of the school is far to reach. In addition, the existence of facilities and other supporting aspects for the school are not much, such as road infrastructure. The difficult location and access caused the number of students enrolled was only about 30 in each year. The school access is the main cause that makes people less motivated to send their children to that school.

Third, government provided some equipments and capital facilities. Regional and national governments (such as PNPM) collaborate to provide access and facilities to increase income and welfare by providing vessels and other fishing gear. Government facilitated fishermen some fishing gear such as a motorboat used for fishing, and fishing gear in the form of nets or rawai. The catch of fish is divided into two parts consisting of fish with high economic value are directly sold to collectors for export, while less value fish are directly sold to anyone with very cheap price. The government provides the aid of fish processing equipment so that these fish can have high economic value. The aid is given to PKK groups or mothers and wives of fishermen family.

The government also involves other stakeholders such as the National Aeronautics and Space Agency (LAPAN) to distribute ZPPI (Potential Fishing Zone) tools to the fishermen. This tool will help the fishermen to fish in the sea. It serves as a fish detecting radar. The tool aims to increase the catch of fishermen who ultimately improve the fisherman's economy. The provision of aid tools is also followed by the socialization and training on the use of tools as well as their practical guidance. The granting of these fishing gears is given to traditional fishermen of long lines, in order to increase their catch in the sea. The aid of fishing gear is provided in the form of larger ships or nets in order to catch more fish and wider their fishing position.

Fourth, to establish a fishing village. The government of Bengkalis has established a village and some houses that are given primarily to the fishing communities who cannot afford them. The government created this program for traditional fishermen in the district areas such as Bantan, Bukitbatu and Rupat .Related to this, one of the informants from the Department of Marine Affairs and Fisheries, Ir. Ansharuddin said that the program aims to organize and build a good house and proper sanitation for fishermen. The government also want to manage the settlement area of fishermen (interview, September 5, 2016).

However, the existence of fisherman's settlement is not supported by adequate facilities as a proper place to live. Even the free time had to waste since there were no proper facilities. After long times, electricity is finally come, but not for water, because drinking water, washing water, and water for bathing have to be taken from rainwater. This is due to their coastal position right on 
the beach where water access is difficult. Facilities for auctioning or selling fish are provided, but since it is away from the crowds, it ultimately does not work. In addition, fishing communities do not get much direct guidance or sustained empowerment. In other words, facilities are provided but not equipped with knowledge and expertise to maintain and use the facilities.

The development of fisherman's residential area is closely related to the sustainability of marine ecosystems in coastal areas. It would control the habitat and community life including the life of the fish that became an icon of the city of Bengkalis: the Terubuk fish. Due to the program of protection and conservation of coastal and marine natural resources, it also aims to protect the coastline due to the high abrasion rate. The high coastal abrasion caused the land to diminish, as there was no defense of trees such as mangroves, which also caused the decline of small fish species. Government steps to plant mangrove trees along the coastline must be supported and involved fishermen, because their lives are highly dependent on the sea.

Fifth, developing some tourist villages. The tourist village is developed through a simple concept. Village tourism development program is marketing the fishing village as an object of tourism. Villages that rely on natural wealth, culture, and art alone are not enough to boost the number of tourist visits. But the village should also be supported by the ability to produce and develop products to be sold, which must have added value and has distinctive characteristics that differentiate with other regions. Meskom Village and Prapat Tunggal in Bengkalis Subdistrict have not only natural tourism, but also the potential of art, cultures, tradition with its charming objects, and producer of shrimp paste and crackers.

The identity of Meskom Village, among others, is the high stage house that has a unique form. It has regional specialties such as belacan, cencaluk, tempoyak, spicy acid, and kepurun, the material from sago. Meskom Village has another name of "Kampung Zapin". Although, not all citizens of Meskom understand zapin deeply, but in one family no one cannot play zapin. In addition to zapin, villagers also have other types of art which are kompang, robana, and pencak silat. This village also has a game that can be interesting to be enjoyed by tourists such as traditional games of jung, gasing, and kite.
Based on that, the empowerment of fisherman communities becomes important along with the existence of tourist areas. The Bengkalis government in synergy with several agencies has promoted coastal tourism areas such as the Selat Baru (New Strait) and Rupat Utara (Northern Rupat). Both of these places become the main program to be developed as tourism object. The local government always try to improve the image of the district of Bengkalis and Nort Rupat because of their beautiful shores. Some annual program and activities are often made in these places to support and promote this tourist area. Some of the activities undertaken are the Selat Baru Beach Festival with various races, beach festival Rupat, Safar bath ritual, and so forth.

\section{Media of Communication in Fisher- men Empowerment Program}

The media of communication to empower fishermen are all the means used in implementing the fishermen empowerment program. Media is very important to produce, reproduce, and distribute the meaning of both the government and the fishing communities. Therefore, the communication media becomes something instrumental in people's lives. The use and access of the media should be able to improve the welfare and living standards of fishing communities. Nevertheless, the main government's choice of media is very limited and even not functions optimally.

First, the news media in the form of mass media coverage such as Riau Pos, Tribun Pekanbaru, portal news and other media institution. The publication purpose is to convey information to the fishermen and general public about the programs related to them and the government undertakes to improve the welfare of the fishermen community.

Second, the website and social media. The government uses this internet because it is now the most popular media, especially among young people. This is in line with the number of programs that want to be disseminated to the community; on the contrary, public needs information directly from the government. Although there are people who are able to access this media, but the number is few and very limited. This media existence is very important and quite practical and fast in penetrating, especially among educated people who accustomed to access information technology. Even the future of this media becomes prominent and 
potential for the wider level of its use by the community. However, this media-based media is not maximized by the government due to the tradition or culture of government employees' work and their nonoptimal service functions.

Third, using some billboards and banners. Outdoor media is widely used by the government to disseminate and provide information to the fishing community. Many socializations contained informative or persuasive messages that were placed in several locations near the fishing community's settlements. Here is an example of the message: "Hutan Mangrove Rindang, Ikan dan Udang Riang; Masyarakat Senang, Rezki Pun Datang" (Mangrove forest is densed, fish and shrimp dance; People are happy, because they earn the money). Some messages are made overlapping, as found on the sign of a fishermen's settlement: "Laut Masa Depan Kita" (The Sea is Our Future). The messages made are generally not appropriate, either from the planning side of the message and its typology. The background color options and messages that are delivered are unattractive, generally faded quickly, and the location is not the way it should be.

Fourth, using calendars and posters. The use of media for empowerment is not as massive as those political campaigns. Various media such as posters, stickers, calendars, wall clocks, and others are widely used in political campaigns. But for the activities of government programs in fishermen empowerment, it is very limited. Its appearance is only in one type of media, not vary in a large amount. Calendar as a medium, produced in limited quantities, and distributed to a limited group of fishermen. The message of empowerment will be effective when diversified in the message and media type.

Fifth, creating a film/animated movie. The creation and dissemination of messages for community empowerment through animated films has been conducted by the Marine and Fisheries Agency in cooperation with Marine and Coastal Resources Management Project (MCRMP). One of his films is entitled "The Adventure of the Land of Visitors: The Squanders of the Sea". This animated film is an animated series of "Love the Early-Possible Environments", which contains messages on the importance of keeping the sea and its contents by not littering the sea, maintaining the environment of mangrove forests, and many others. This film is about the experience of Alfath, Dullah and Aulia as junior high school students, who were in the sea aparted Rangsang Island and the city of Bengkalis. In their journey with Alfat's father, they met many events. The film is narrated with a less clear visualization and less interesting from both the picture and the lighting. However, the packaging has been widely varied in the form of chanting or Malay culture typical of chanting.

This media choice is disseminated through various meetings and other socialization, whether in the extension and/or schools. The screening of this film is limited. The film distribution in the form of $C D$ aimed to the public or children in school as the main target segmentation of the message communication. The Office of Marine and Fisheries uses this media as a campaign or delivery of messages to make the public cares and involve in government programs in developing fishing and sea communities.

Communication is very important to be spread through various messages and types of media in penetrating audiences. The message developed certainly adjusts the needs of the fisherman as the audience. The media and its messages should be easy to find at various strategic points: at public roads, intersections, social media, newspapers, and other non-mass media such as meetings among fellow fishermen to remind each other. Thus, the empowerment of fishermen can be done by reminding and involving in wherever and whenever they would be to always keep the marine environment safe and more prosperous. The media must be closer to the community and adjust to the characteristics of the community.

\section{The Model of Communication in Em- powering Fishermen Community}

Building a good society can be done by building a good communication pattern. The government and the society are two complementary sides that should build participatory communication to each other. As Faridah, et al. (2014: 243) pointed out that in a participatory communication approach, all the problems faced are a common problem, and the way to solve them must be considered together. This model shows the interactive situation among the parties that communicate according to the context and the dynamics of the community. Social dynamics of society will certainly affect the behavior of communication 
delivered by every individual in society. Similarly, the communication process will affect and reflect the lifestyle of a society, since communication among humans always takes place in an atmosphere full of values, such as tradition, customs, culture, religion, ideology and political orientation.

To empower fishermen, it needs a form of communication that conditions them to freely open up and express themselves according to their values and address all issues without any constraints. Therefore, empowerment can not only rely on one or two ways, but must be done in a variety of ways, efforts, and mix of creative media communication. Silviyanti (2016: 15) discloses that community empowerment should employ a variety of ways, including the media that should pay attention to the characteristics of the fishermen such as age, education, and work experience and income level.

The model of communication in empowering fishermen is dominantly delegated to Department of Marine and Fishery. This department formulates policies in the field of Marine and Fisheries, organizing the policy and other public service-related, including empowering the fishermen. As for handling the case of fish theft by foreign fishermen, the case of clash between traditional fishermen and modern fishermen, and community empowerment, the Office of Marine and Fisheries often involve the
Police officers, water police unit (POL AIR), Indonesian Navy (TNI-AL), Army (TNI AD), Syahbandar, Telecommunication and Informatics Transportation Agency, Environment Agency (BLH) and others, in accordance with the authority of each service. All are involved in making an agreement to empower traditional fishermen throughout Bengkalis Regency as one of the efforts to overcome illegal fishing (fish theft). The important thing that becomes the subject of coordination involving related parties is the empowerment of traditional fishermen. Nurjanah, et al. (2017: 3) states community empowerment delivery as starting point for the community's independence in order to improve their life by using and accessing local resources as possible.

Rasyid (2015: 507) also explains that community development is clearly a mandate of the 1945 Indonesia Constitution and should be the focus of attention and responsibility of all parties, government, private business, and the society itself. Therefore, the program of the development and the community empowerment in Bengkalis Regency is based on the rules according to predetermined nomenclature of the Ministry of Home Affairs, National government program through Community Empowerment (PNPM), private with CSR, and local government with various communication activities of training, counseling, assistance, socialization, and so

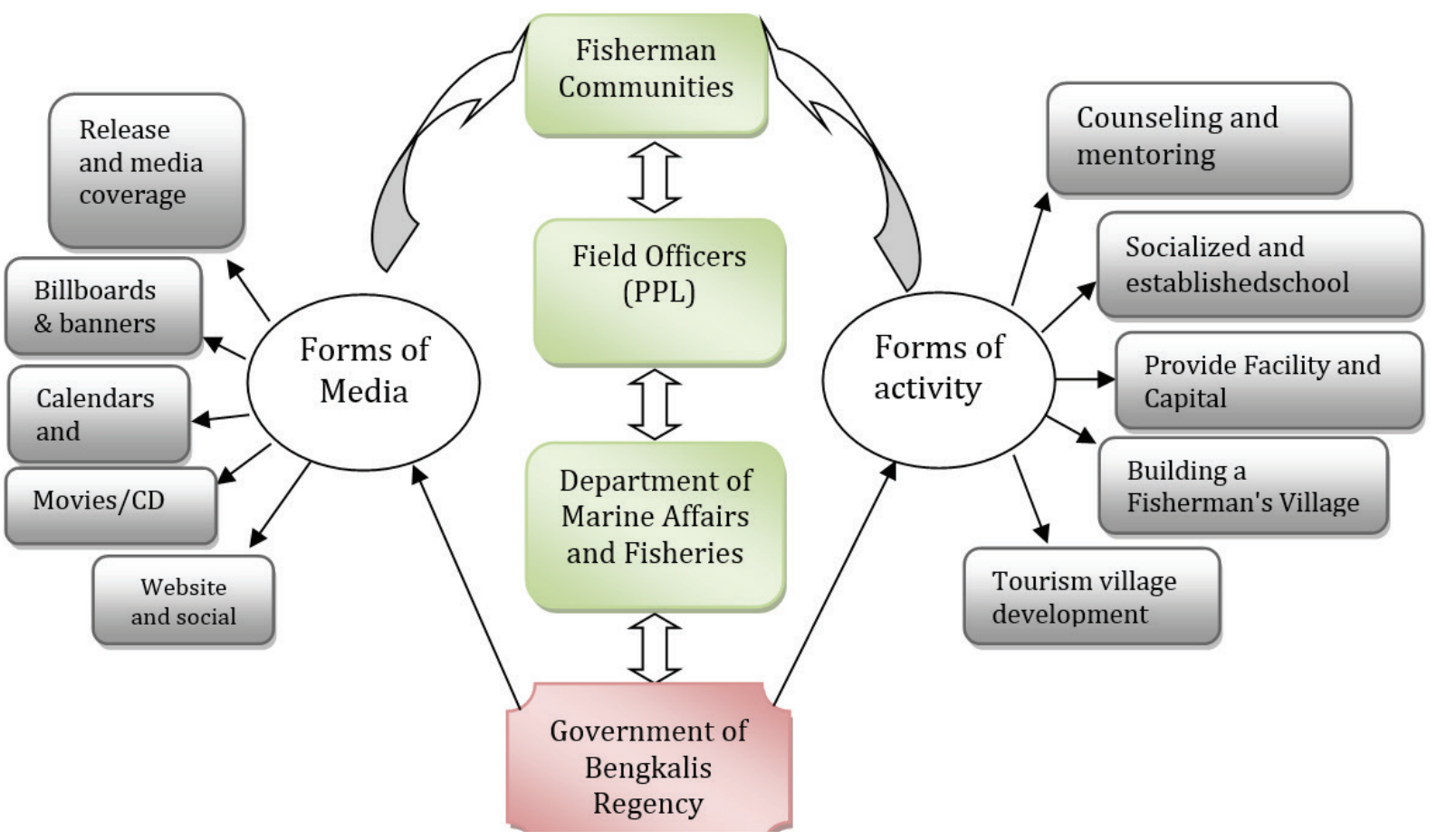

Figure 1: The Model of communication to empower fishermen in Bengkalis Regency 
on.

The activities of the Maritime and Fisheries Department are clearly based on their main tasks and functions and constrained by the budget of ABPD. The activities of empowerment are often neglected by routine administrative activities in the internal service compared to direct service to the field to the community. Nevertheless, the form of communication empowerment and use of communication is done nonoptimal. The implementation of community empowerment activities relies more on Field Supervisory Officers (PPL) as an extension placed in the Technical Implementation Unit of the Service (UPTD) located in the district. Peoples can interact personally with these officers. They have very limited action to act and communicate. Therefore, the limited communications by the government limit the success of the empowerment program.

In the implementation of government programs, communication activities become important. The government must be able to create participative way of communication within the government as well as the public or public beneficiaries of the program. Based on what has been discussed previously, writers make a model of communication in empowering fishermen community in Bengkalis Regency. The more details information can be illustrated in figure 1.

Model of communication to empower fishermen community is an important agenda for the implementation the government policy. There are some shapes of communication to empower and some media and channels used by the government. The communication is not yet optimal. The policy approach to community development and sustainable development is needed to improve the communication model.

\section{Conclusions}

The model of communications to empower fishermen community is dominantly done by Marine and Fisheries Agency through field officers (PPL). PPL have a duty to communicate and transform the community in accordance with the needs of the community and government. The other communications are mentoring and counseling, socialization and establishment of fisheries school, providing facilities and capital, building fishing village, and developing tourist village. But there are still many obstacles in the implementation process due to inadequate human resources, namely the limited number of the field officers. This limitation is caused by the restricting of government budget.

The media used in empowering the fishermen are internet-based media, news release, billboards and banners, calendars and posters, and films. Unfortunately, the existence of these media is still far from the ideal, both in terms of quantity and quality of packaging and the contents of the message.

The communications in empowering fishermen and coastal resource management should be planned in the form of sustainable communication activities. Selected communication media must be created and packaged in creative ways, scattered and diverse in media forms. Communication messages will be effective if there is a variety of media forms and its content. The government should increase quantity and quality of the existence of PPL. PPL should be provided with training in designing messages and communications to deliver them appropriately. Therefore, the government should also pay attention to socio-psychological factors that tend to be passive in responding to the innovation offered. The governments should enhance understanding of innovations through information technology, and should be supported by improving sustainable communications in order to use the facility appropriately.

Various research approach can be used to continue this research. The ethnographic approach of communication to understand the traditional fisherman, culture and local wisdom. The effective communication methods can be also measured by survey research.

\section{References}

Amanah, S. (2010). "Peran Komunikasi Pembangunan dalam Pemberdayaan Masyarakat Pesisir". Jurnal Komunikasi Pembangunan. Volume 8 Number 1: 1-19.

Faridah, D., et al. (2014). "Optimasi Pusat Layanan Internet Kecamatan dalam Meningkatkan Aksesibilitas Masyarakat terhadap Informasi", MIMBAR Jurnal Sosial dan Pembangunan, Volume 30, No. 2: 243-252.

Govindaraju, P., \& MabelM.M (2010). "The status of information and communication technology in a coastal village: A case study", IJEDICT, 2010, Vol. 6, Issue 1, pp. 128-135.

Hamijoyo S.S. (2005). Komunikasi 
Partisipatoris: Pemikiran dan Implementasi Komunikasi dalam Pengembangan Masyarakat. Bandung Humaniora.

Huberman, A.M. \& Matthew B.M. (2010). Analisis Data Kualitatif. Terjemahan Tjetjep Rohendi. Jakarta: UI-Press.

Moleong, L.J (2010). Metodologi Penelitian Kuantitatif. Bandung: Remaja Rosdakarya

Nugroho, D.R., etal. (2016). "Model of Communication in Corporate Social Responsibility Program to Empower Communities". MIMBAR Jurnal Sosial dan Pembangunan, Volume 32 Number 2:254-266.

Nurjanah A., et al. (2017) "Dialogic Communication Patterns between Company-Community in Achieving Community Empowerment In Indonesia: A Case Study of Waste Problem". Global Media Journal, 15: 28.

Nurjanah, (2015). "Peran Komunikasi Persuasif dalam Penyelesaian Konflik Antara Nelayan". Jurnal Ilmu Komunikasi. Volume 6 Nomor 2: 128-142)

Rasyid, Anuar, et.al. (2015). "Komunikasi dalam CSR Peruahaan: Pemberdayaan
Masyarakat dan Membangun Citra Positif", MIMBAR Jurnal Sosial dan Pembangunan, Volume 31, Number 2: 507-518.

Sartika, I. (2011). "Evaluasi Kebijakan Pemberdayaan Nelayan". Jurnal Ilmu Administrasi Negara. Volume 11 Nomor 2: 11-124.

Silviyanti, Serly, et al. (2016). "The Influence of Communication Media Usage towards Fishermen's Empowerment in Pasaran Island", MIMBAR Jurnal Sosial dan Pembangunan, Volume 32, Number 1: 9-16.

Sulistyowati, F., et al. (2005). Komunikasi Pemberdayaan. Yogyakarta. APMD Press.

Widjajanti, W.W. (2016). "Strategy and Planning Model Village Fishermen Coastal Area in Surabaya". International Journal of Applied Engineering Research. Volume 11 Number 4: 2486-2493.

Zulfera, et al. (2014). "Faktor-Faktor yang Berhubungan dengan Keberdayaan Petani Sayur Organik di Kabupaten Agam dan Tanah Datar, Provinsi Sumatera Barat", MIMBAR Jurnal Sosial dan Pembangunan, Volume 30, no 2: 149-158. 